\title{
Properties of Debadib Evaporates (Northern Tunisia) for Potential Use in Industrial Fields
}

\author{
Imed Ben Salah ${ }^{1}$, Moufida M’barek Jemaii ${ }^{1}$, Narjess Karoui-Yaakoub1, Ali Sdiri², \\ Noureddine Ben Ayed ${ }^{1}$ \\ ${ }^{1}$ Department of Geology, Sciences University of Bizerte, Bizerte, Tunisia \\ ${ }^{2}$ Department of Georesources and Environment, National Engineering School, University of Sfax, Sfax, Tunisia \\ Email: *imed_bensalah@yahoo.fr
}

How to cite this paper: Salah, I.B., Jemaii, M.M., Karoui-Yaakoub, N., Sdiri, A. and Ayed, N.B. (2016) Properties of Debadib Evaporates (Northern Tunisia) for Potential Use in Industrial Fields. Open Journal of Geology, 6, 1525-1538. http://dx.doi.org/10.4236/ojg.2016.612108

Received: October 25, 2016

Accepted: December 17, 2016

Published: December 20, 2016

Copyright $\odot 2016$ by authors and Scientific Research Publishing Inc. This work is licensed under the Creative Commons Attribution International License (CC BY 4.0).

http://creativecommons.org/licenses/by/4.0/

\begin{abstract}
Gypsum is widely distributed in Tunisia occurring in the formation of Triassic age. The gypsum deposit of Mellegue is the alabastine type with a little of the porphyroblast type and contains traces of clay minerals and calcite. It is a moderately strong rock in terms of its unconfined compressive strength of $16 \mathrm{Mpa}$ and tensile strength of 3.35 Mpa. Triaxial testing values indicated an apparent cohesion of $10 \mathrm{Mpa}$ and an angle of friction of $26^{\circ}$. The gypsum studied had a percentage of $\mathrm{SO}_{3}$ of $41.71 \%$ and a percentage of $\mathrm{CaO}$ of $32.9 \%$. All the samples had low densities according to the International Association of Engineering Geology (IAEG) classification and exhibited a moderate porosity whether effective or absolute. The gypsum proved to be moderately strong when tested in unconfined compression and tensile strength. Thermal analysis indicated a total weight loss of $20.27 \%$ and the whiteness index about $90 \%$. This proved a high degree of whiteness. The time of setting can be considered short and medium, which is quite favorable for industrial application compared with other gypsum deposits currently operated.
\end{abstract}

\section{Keywords}

Triassic Gypsum Deposit, Mineralogical Analysis, Physicochemical Analysis, Geotechnical Testing, Industrial Use

\section{Introduction}

Gypsum is exceptionally distributed in the formation of Triassic age in Tunisia. In the study area, it is essentially a set of chaotic gypsum intercalated by marl and multicolored sandstones with a layer of ophites. Gypsum, a calcium sulfate dehydrate compound can undergo various treatments and be used for a various range of industrial 
and environmental application. Indeed, the importance and the industrial needs for gypsum are continuously increasing due to its environmental friendly use. This work is considered as one of the first approaches for the recognition of Triassic evaporates deposits in the northwest of Tunisia.

In this context, the present work aimed to add further details about the gypsum deposits of Northern Tunisia for potential valorization in plaster industry. Undisturbed samples of gypsum were collected from various locations of the study area and tested in the laboratory to determine their potential use in the industrial fields.

\section{Location and Geological Setting}

The study area is affected by a morphological complex that attaches to the north of the country which is separated by the valley of the Medjerdah [1] [2]. All structures in this region, which are placed in the subsiding area and called "Tunisian collapse", have the general direction of the Tunisian Atlas [3]. In the study area, the Triassic rock is represented by complex domes occupying large structures named Jebel Eddbadib [4]. It is presented buy chaotic gypsum intercalated by marl [2] [5] [6] and multicolored sandstones with a layer of ophites [2] [7]. Several researchers focused on natural and synthetic calcium sulfate dehydrate for industrial applications [8]-[17]. Among those researchers, Mansour et al. [12], Ben Ali et al. [18], Sdiri et al. [19] paid their attention to the application of Tunisian gypsum for construction and buildings. The Triassic is represented by saliferous complex which occupies large areas such as Jebel Eddbadib. It is a chaotic set of, limestone, micaceous and especially gypsum. We can raise bi-pyramids quartz dyed brown by iron hydroxide, dolomite and pyrite crystals. This complex salifaires "occupy positions or extrusive Diapiric which always leads to abnormal contacts" [20]. In the study area, outcrops of Triassic are often punctuated by abnormal contact, Ghanmi M [4] and some of these outcrops are interpreted by Villa et al. [21] [22] as salt glaciers. The diapiric complexes are in fact independent lithostratigraphic unit known as Rhéouis formation [1]. Their age has caused controversy [23] [24] [25]. Gottis, S. [26] found that "the Tunisian Trias shows remarkable consistency." This Diapiric outcrop consists of a huge blocks of gypsum and siliceous limestone, shales and sandstones with some colorful past of ophitic to epidotic layers. The Outcropping of Debadib evaporates extends largely more than $20 \mathrm{~km}$ (Latitude: $36^{\circ} 10^{\prime} 27^{\prime \prime N}$; Longitude: $8^{\circ} 42^{\prime} 17^{\prime \prime E}$ ). This study has worn on thirty samples Deb1 Deb30, collected in a Triasic gypsum (Figure 1), at $15 \mathrm{~km}$ from the Kef city. The lithology of this outcrop is described in Figure 2. It is well known that gypsum and plaster are mainly composed of calcium sulfate [19]. Nevertheless, some impurities added may be beneficial for plaster and other particular applications of gypsum.

\section{Materials and Methods}

The methodology adopted in this work is described in Figure 3. Particle size analysis was performed by a laser granulometer type Malvern Mastersizer 2000. Gypsum samples were ground then sieved with a sieve of $125 \mathrm{~mm}$ diameter. A portion of the 


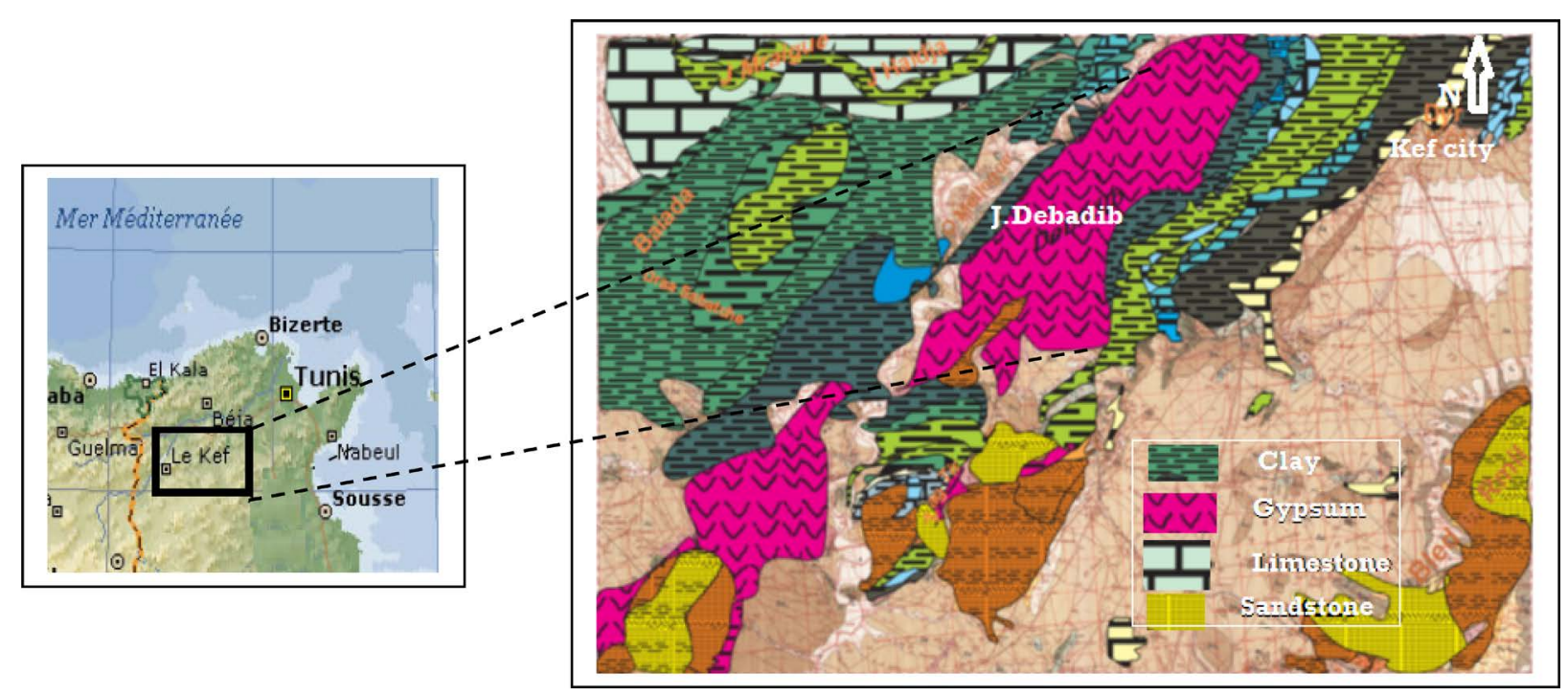

Figure 1. Location of the study area.

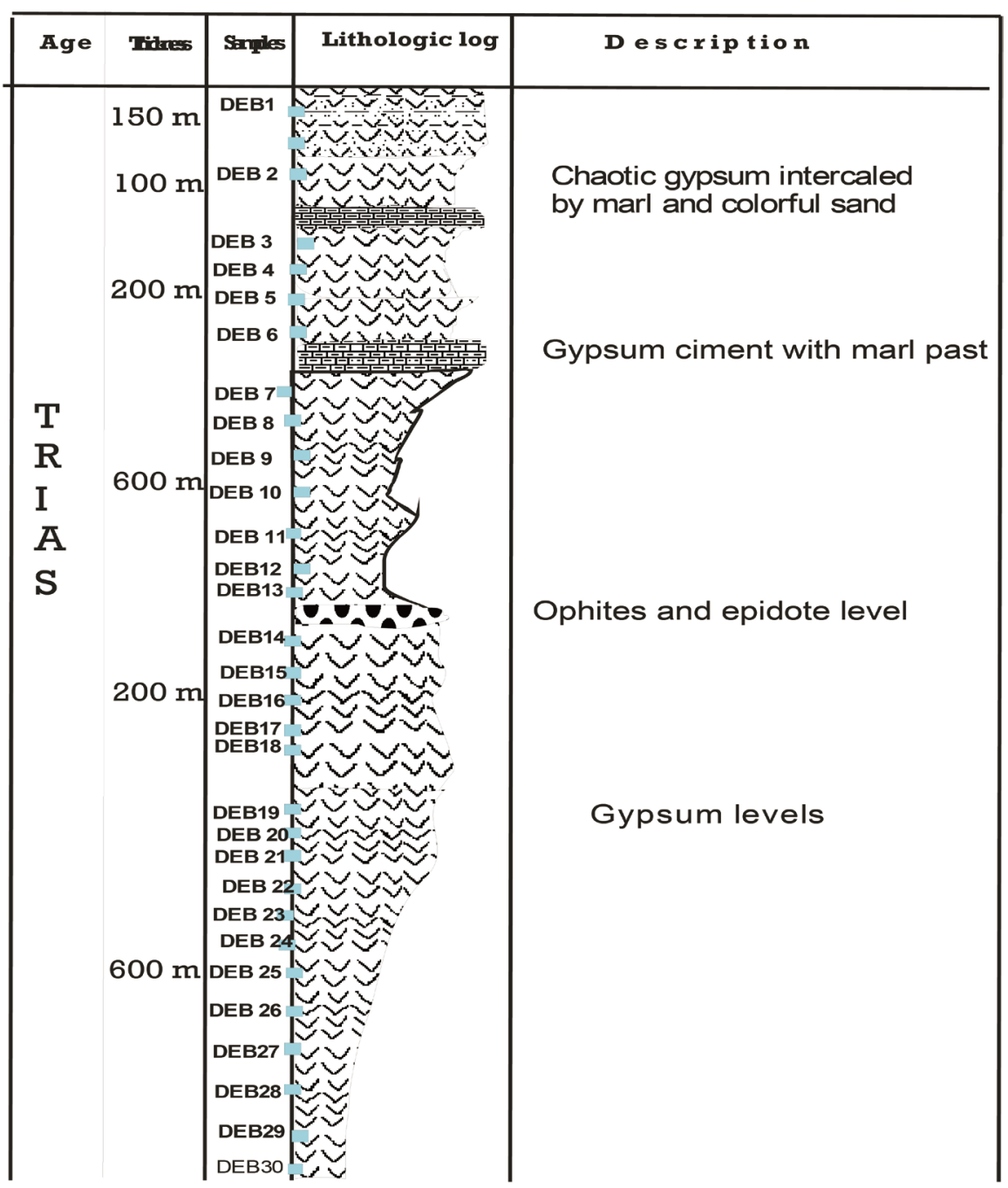

Figure 2. Stratigraphic sequence for the gypsum section of J. Debadib-Mellegue. 


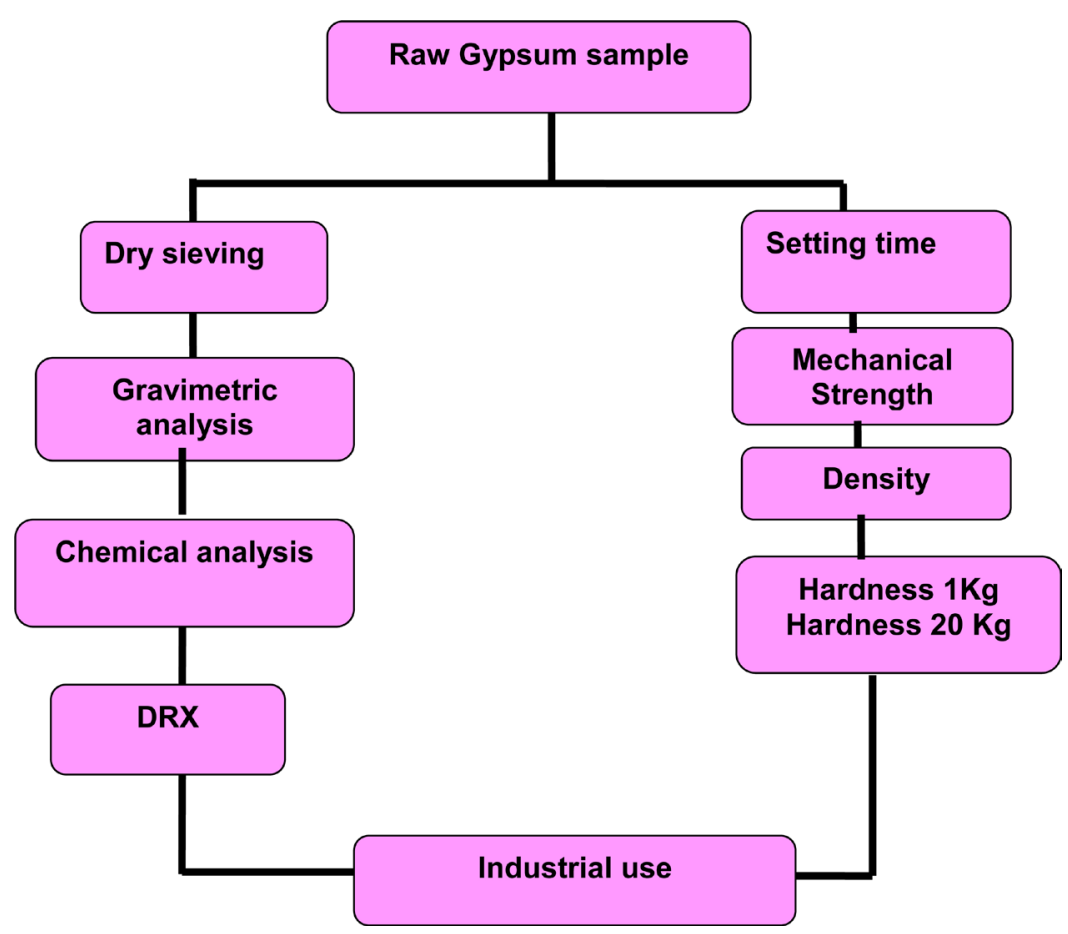

Figure 3. Gypsum studied methodology.

fraction less than $125 \mathrm{~mm}$ was dispersed in $100 \mathrm{ml}$ of distilled water and subjected to ultrasound for $30 \mathrm{~min}$. The measurement was made from the solution obtained after dispersion by ultrasound. The particle size distribution was derived from the interaction between the particles and the incident radiation.

Chemical analysis was made on solutions of samples in dilute acids. $\mathrm{SO}_{3}$ was measured gravimetrically by precipitation of $\mathrm{BaSO}_{4}$. $\mathrm{CaO}$ was determined by the precipitation of calcium oxalate. Crystallization water was determined by measuring the loss on ignition at $350^{\circ} \mathrm{C}$ to constant weight [27]. Quantitative complexometric analysis was used to determine $\mathrm{SiO}_{2}, \mathrm{Al}_{2} \mathrm{O}_{3}, \mathrm{Fe}_{2} \mathrm{O}_{3}, \mathrm{MgO}, \mathrm{Na}_{2} \mathrm{O}$ and $\mathrm{K}_{2} \mathrm{O}$ [28]. Loss on ignition was determined by calcination in an oxidizing atmosphere at $1000^{\circ} \mathrm{C}$. The mixing ratio (e/p) was determined according to the density and porosity of the material [29]. The effective porosities of gypsum were determined by use of an air porosimeter. The absolute porosity provides a measure of the total volume of voids in a rock. It's usually determined as the excess of the specific gravity over dry density. The X-ray diffraction analysis is based on the diffraction of a beam of monochromatic X-rays according to Bragg's law. X-ray diffraction analysis was carried out on the whole rock powder gypsum samples. Thermal analysis was performed using an oven with variable temperature and a heating rate of $10^{\circ} \mathrm{C} / \mathrm{min}$. This oven had two thermocouples that record respectively the temperature of the oven and the inert sample. It was therefore possible to obtain a curve showing a series of peaks reflecting the endothermic and exothermic reactions in the sample. During thermo gravimetric analysis, a sample was continuously weighed in an oven at varying temperature. A curve having inflection points represented the reactions due to the action of the temperature such as the dehydration 
of gypsum and half hydrates. IR spectrometry was performed on a sample of powder by means of a spectrometer universal ATR (Attenuated Total Reflectance) sampling accessory of Perkin Elmer spectrometer. Geotechnical tests were carried out on samples taken from plaster according to the NF EN 13279-2 standard [30]. Values obtained were respectively the tensile strength, the compressive strength, triaxial test and hardness. Samples were obtained in stainless steel molds machined with high precision, giving prismatic bars of the dimensions $40 \mathrm{~mm} \times 40 \mathrm{~mm} \times 160 \mathrm{~mm}$ [31]. Whiteness Index test was performed according to the experimental X 08-011 French standards [32]. A dry sample was subjected to light. The amount of reflected light was measured by a photoelectric cell and expressed as a percentage of the quantity of light reflected by a standard.

The setting time was measured with the Vicat apparatus. The plaster cake was cut at regular intervals with the blade of a special knife, held in a vertical plane [33]. The device had a length of $100 \mathrm{~mm}$, a width of $16 \mathrm{~mm}$ and a thickness of $1.5 \mathrm{~mm}$. The final setting time was the moment a touch of a finger (thumb or index) applied to the surface of the dough no longer appears according to EN 13279-2 (2005) [30]. The fluidity was assessed by measuring the flow by spreading the paste contained in a Schmidt ring. The consistency was determined by the method of the shaking table EN 196-3 (2005) [34]. The hardness was obtained by using an apparatus for applying a steel ball at a point of a side surface of the sample. The test was conducted by applying a force on the ball of 10 newtons to 200 newtons in two seconds.

Tensile strength was measured by a brazil test of $40 \mathrm{~mm}$ diameter and $20 \mathrm{~mm}$ high cylindrical samples made of the same material while compressive strength was determined by testing the lateral side of prisms with a section of $40 \times 40 \mathrm{~mm}$ between two hard metal plates of $40 \mathrm{~mm}$ width and a length greater than $40 \mathrm{~mm}$. Triaxial test was performed by a triaxial apparatus according to the NF P 94-074 standard [35] to determine cohesion and friction angle. Values of apparent cohesion and angle of friction were determined from Mohr circle. The value of cohesion was derived by the intersection of the common tangent to the Mohr circles with the vertical axis [36].

\section{Results and Discussion}

Laser particle size was used to determine the granulometric distribution by diffraction technique of the laser light after the sample suspension in a dispersant. The particle size distribution was derived from the interaction between a set of particles and the incident radiation [31].

The Particle size analysis by laser diffraction gypsum indicated a main population centered at $100 \mathrm{~mm}$ characteristic of gypsum (Figure 4). The results had shown that $50 \%$ of the grains had a diameter less than or equal to $75 \mathrm{~mm}$ and $90 \%$ had a diameter less than $152 \mathrm{~mm}$. The amplitude and the largest dispersion extended about $100 \mathrm{~mm}$. The physico-chemical results were presented in Table 1 . The percentage of $\mathrm{SO}_{3}$ in the samples was ranging between $40.03 \%$ and $44.97 \%$. The complexometric analysis revealed that the $\mathrm{CaO}$ content was very high and varied between $30 \%$ and $35 \%$. The percentage of $\mathrm{Al}_{2} \mathrm{O}_{3}$ was very low and didn't exceed $0.3 \%$, the $\mathrm{MgO}, \mathrm{SiO}_{2}$ and $\mathrm{Fe}_{2} \mathrm{O}_{3}$ con- 


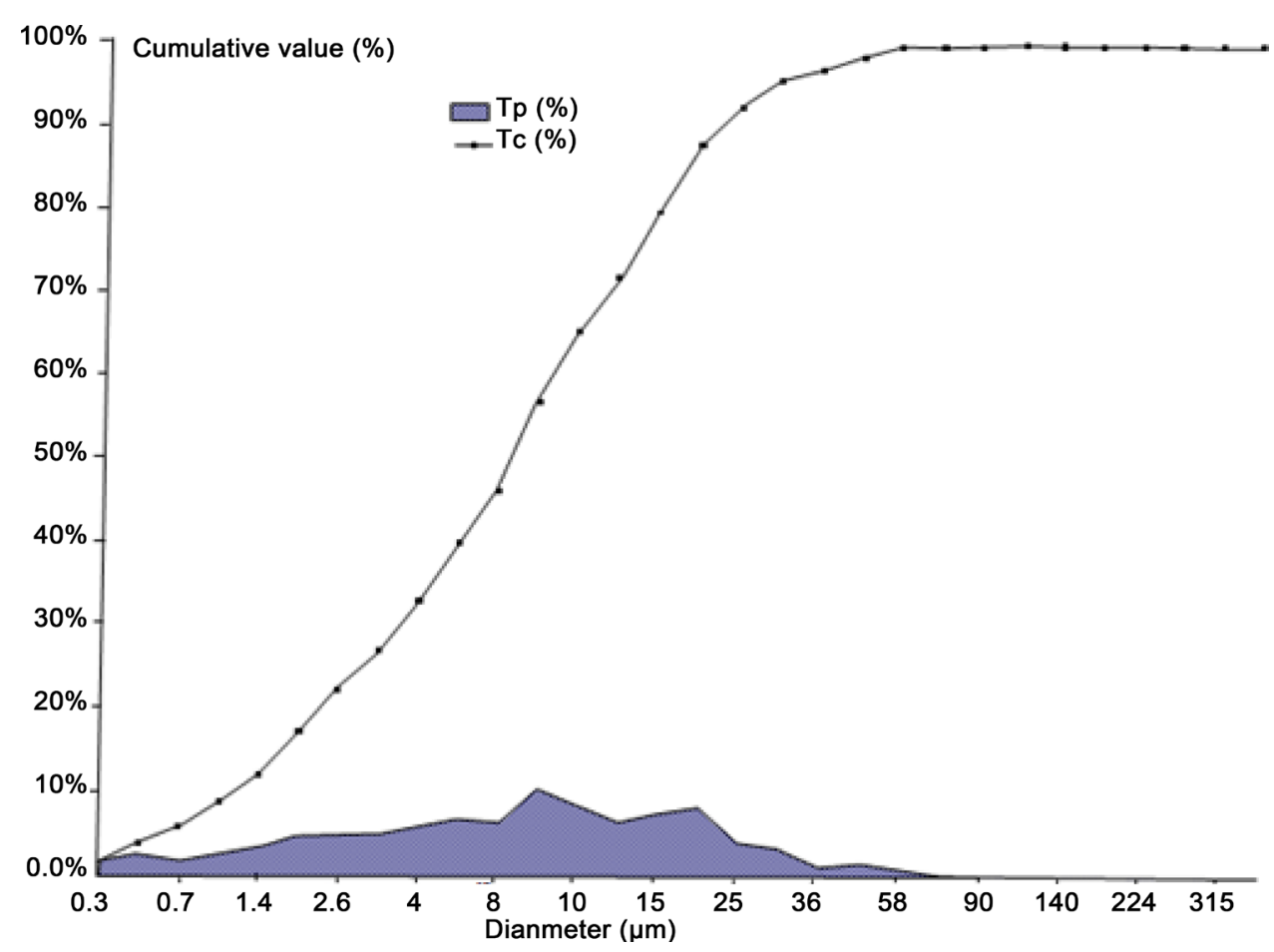

Figure 4. Particle size analysis of Debadib Gypsum.

Table 1. Physico-chemical properties of gypsum, range and average values.

\begin{tabular}{cc}
$\mathrm{SO}_{3}(\%)$ & $40.03-44.97$ \\
$\mathrm{CaO}(\%)$ & 41.71 \\
& $30-35$ \\
$\mathrm{Al}_{2} \mathrm{O}_{3}(\%)$ & 32.9 \\
& $0.1-0.5$ \\
$\mathrm{SiO}_{2}(\%)$ & 0.3 \\
& $0.12-0.36$ \\
$\mathrm{Fe}_{2} \mathrm{O}_{3}(\%)$ & 0.24 \\
$\mathrm{MgO}(\%)$ & trace \\
Absolute Porosity (\%) & trace \\
& $11-12$ \\
Effective Porosity (\%) & 11.65 \\
& $7-9$ \\
Specific gravity & 8 \\
& $2.22-2.46$ \\
& 2.34 \\
\hline
\end{tabular}

tents were very low (traces). These percentages indicated the purity of the gypsum studied. The study of the water content of the different samples of plaster showed that water absorption varied between $7 \%$ and $9 \%$, the percentage of crystallization water was about $19.58 \%$. The porosity was close to $12 \%$, which reflected moderate porosity ac- 
cording to IAEG classification [37]. The specific gravity values determined in this study (2.22 and 2.4) were close to the value suggested by Deer et al. [38]. All of the samples tested can be considered to be of low density according to the IAEG classification and had not presented significant variations due to the absence of impurities. All samples of gypsum possessed medium porosity whether effective or absolute according to the IAEG classification.

The Mineralogical analysis by X-ray diffractogram of the whole rock powder can be seen in Figure 5. The rays (7.50, 4.25, 3.78, 3.05, 2.86, 2.21 and 2.05) of diffractogram were all characteristics of the gypsum [38]. In addition to the characteristic rays of the gypsum, others rays were observed, which indicated the presence of impurities. According to X-ray diffraction the gypsum $\left(\mathrm{CaSO}_{4}, 2 \mathrm{H}_{2} \mathrm{O}\right)$ represented $98.44 \%$ by mass. The thermal behavior of samples was studied by Thermo gravimetric analysis (TGA) and differential thermal analysis (DTA). The endothermic peak at $30^{\circ} \mathrm{C}$ was accompanied by an increase in mass respectively $1.56 \%$ (TGA curves). It may be due to oxidation of certain elements. Major endothermic peaked between $150^{\circ} \mathrm{C}$ and $180^{\circ} \mathrm{C}$, the maximum of which positioned at $138^{\circ} \mathrm{C}$, corresponding to the desorption of a part of the molecules of water adsorbed and structural Gypsum $\left(\mathrm{CaSO}_{4}, 2 \mathrm{H}_{2} \mathrm{O}\right)$ partially dehydrated, forming gypsum $\left(\mathrm{CaSO}_{4}, 1 / 2 \mathrm{H}_{2} \mathrm{O}\right)$. This explains the mass loss on the ATG curves. This loss of mass was $15.8 \%$. The exothermic peaks at $336^{\circ} \mathrm{C}$ were not accompanied by a loss of mass on ATG curves; however, the exothermic peaks at $935^{\circ} \mathrm{C}$ were accompanied by a weight loss of $4.47 \%$. This can be explained by the decomposition of anhydrous gypsum $\mathrm{CaSO}_{4}$ into $\mathrm{CaO}$ and $\mathrm{SO}_{3}$ [29]. The total weight loss was about 20.27\% (Figure 6). The IR gypsum spectrum (Figure 7) indicated bands respectively around $1110.43 \mathrm{~cm}^{-1}$ and $668.9 \mathrm{~cm}^{-1}$ showing the presence of S-O connection. Others bands were around $3503.2 \mathrm{~cm}^{-1}$ and $1615.75 \mathrm{~cm}^{-1}$ and were characteristic of the $\mathrm{O}-\mathrm{H}$ connection [28].

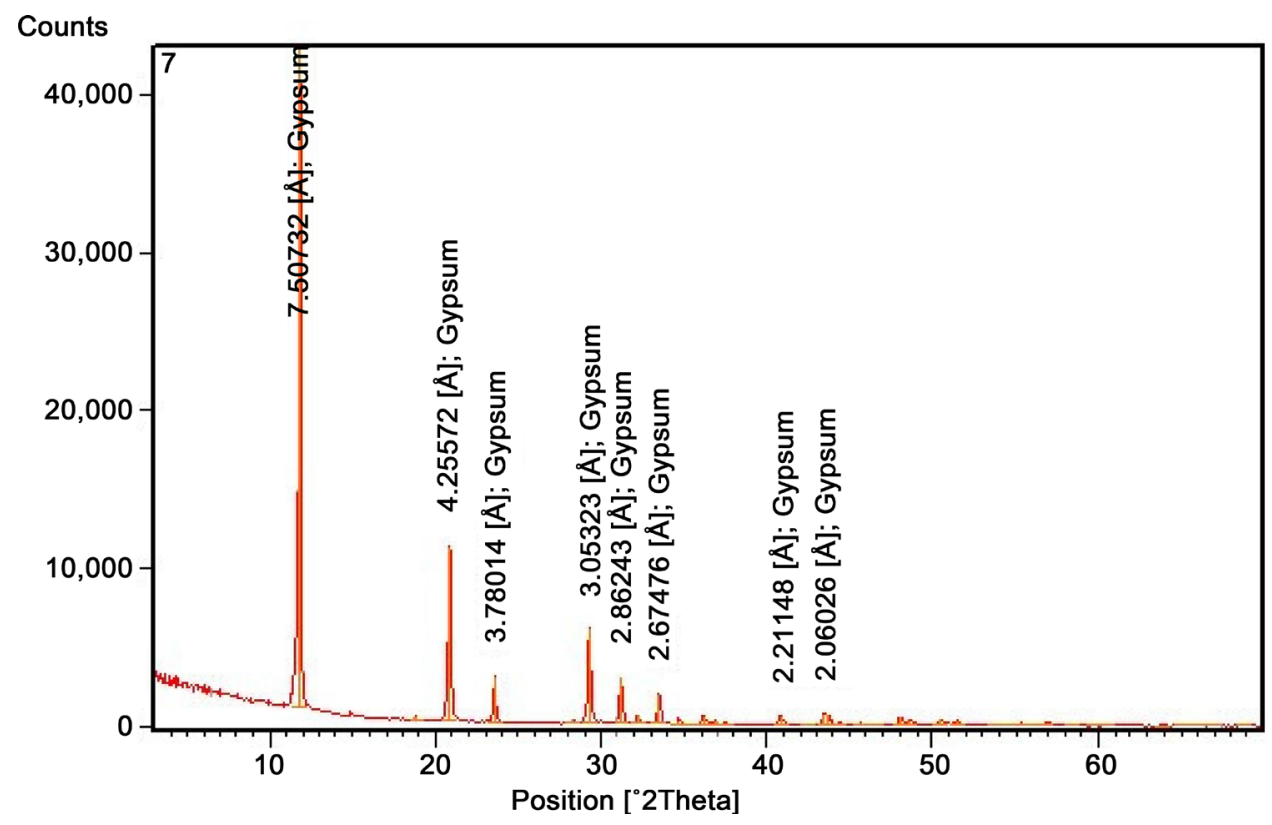

Figure 5. X-ray analysis for gypsum from the Mellegue area. 


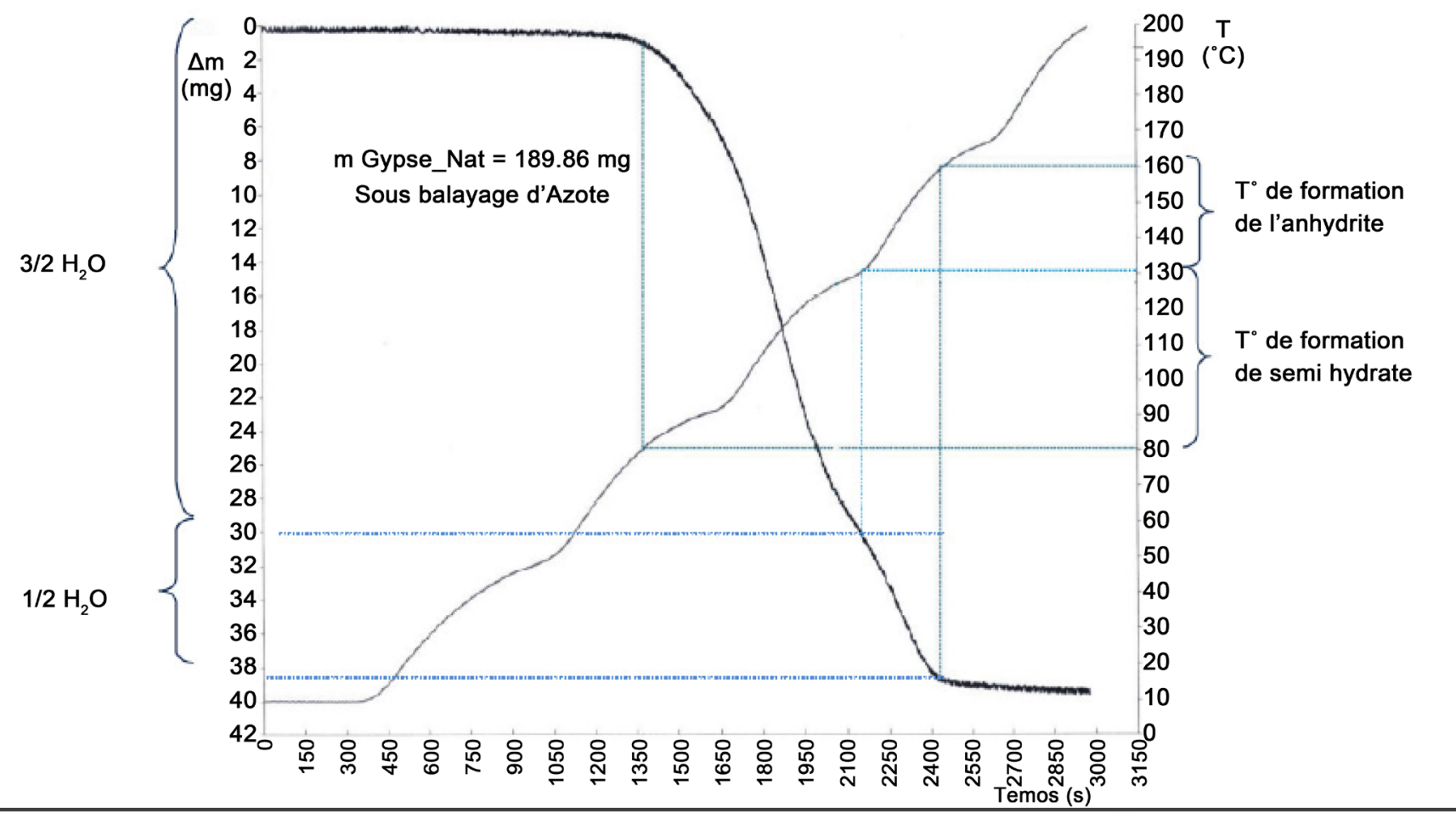

Figure 6. Thermal analysis for gypsum from the Mellegue area.

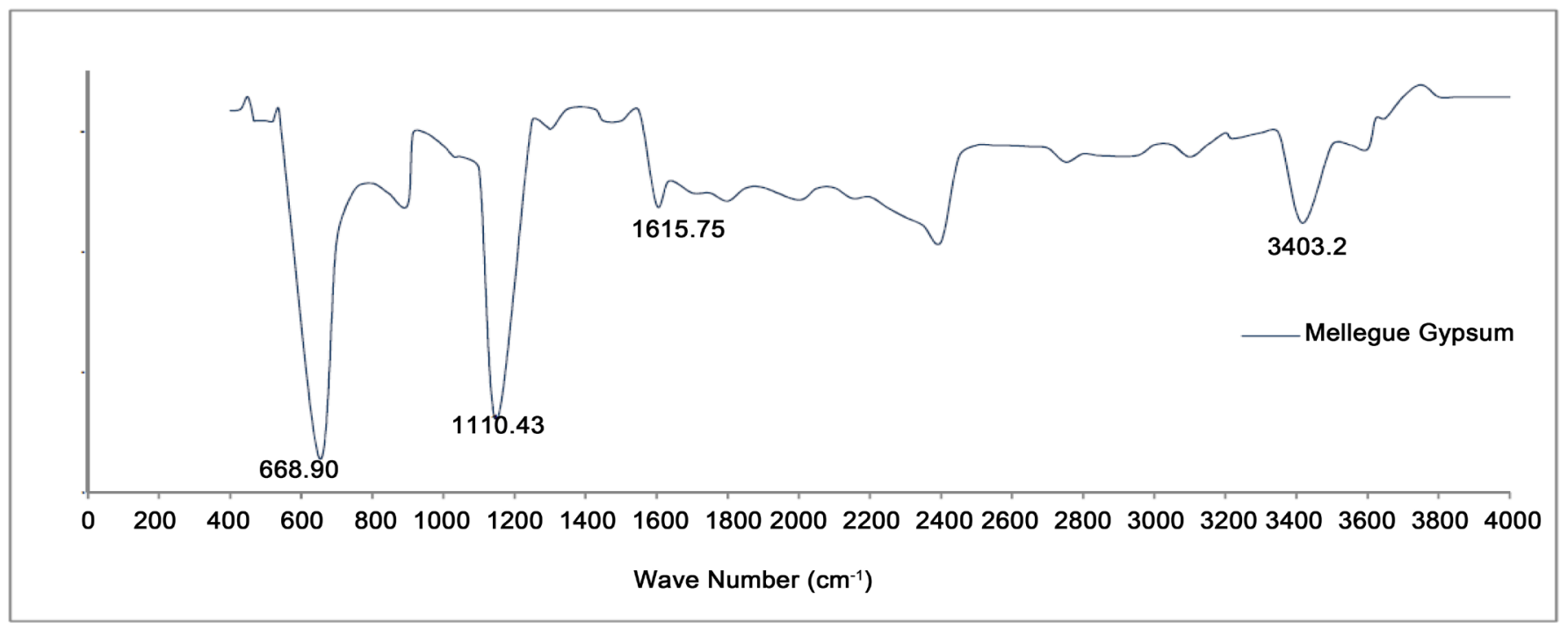

Figure 7. IR Analysis for gypsum from the Debadib area.

According to standard X08-011 [32], the test analysis of whiteness and clarity of plaster samples showed a whiteness index ranging from $85 \%$ to $91 \%$ and a clarity in the light between $60 \%$ and $93 \%$. These results were presented in Table 2 and reflected the purity of the gypsum. This result was confirmed by the measurement of the setting Time which ranged between $6 \mathrm{~min}$ and $17 \mathrm{~min}$. This setting time can be considered as 
short to medium which is quite favorable for industrial application. The mechanical parameters of gypsum from the Debadib area are tabulated in Table 3. All samples of gypsum had the characteristics of compressive strength (14 - 18.55 Mpa) of moderately strong rock according to the classification of IAEG. The lowest values of strength were recorded for the porphyroblastic gypsum and the highest for the alabastine type. The tensile strength proved to be $3 \mathrm{MPa}$. Hardness at $1 \mathrm{~kg}$ presented satisfactory values of 7.49 MPa while the hardness at $20 \mathrm{~kg}$ had a value of $8.5 \mathrm{MPa}$. Samples of gypsum were also subjected to triaxial testing. The value of the cohesion determined through the Mohr circle was $10 \mathrm{MPa}$ while the value of the angle of friction was $26^{\circ}$ (Figure 8).

Table 2. Whiteness index.

\begin{tabular}{ccc}
\hline Samples & Samples Whiteness index (\%) & Clarity \\
\hline $\mathrm{DEB}_{1}-\mathrm{DEB}_{7}$ & $83.69-86.74$ & $60-61$ \\
& 85.21 & 60 \\
$\mathrm{DEB}_{8}-\mathrm{DEB}_{20}$ & $88.66-88.67$ & $80-86$ \\
& 88.66 & 83 \\
$\mathrm{DEB}_{20}-\mathrm{DEB}_{30}$ & $90-91.80$ & $90-96$ \\
& 90.9 & 93 \\
\hline
\end{tabular}

Table 3. Engineering properties of gypsum, range and average.

\begin{tabular}{cc}
\hline Compressive strength (MPa) & $14-18.55$ \\
& 16.28 \\
Tensile strength (MPa) & $0.95-3.35$ \\
& 2.15 \\
Hardness 1 Kg (MPa) & $2-10.11$ \\
& 6.05 \\
Hardness 20 Kg (Mpa) & $7.35-10.76$ \\
& 9.05 \\
Cohesion (MPa) & 10 \\
Angle of friction $\left(^{\circ}\right)$ & 10 \\
& $25-27$ \\
\hline
\end{tabular}

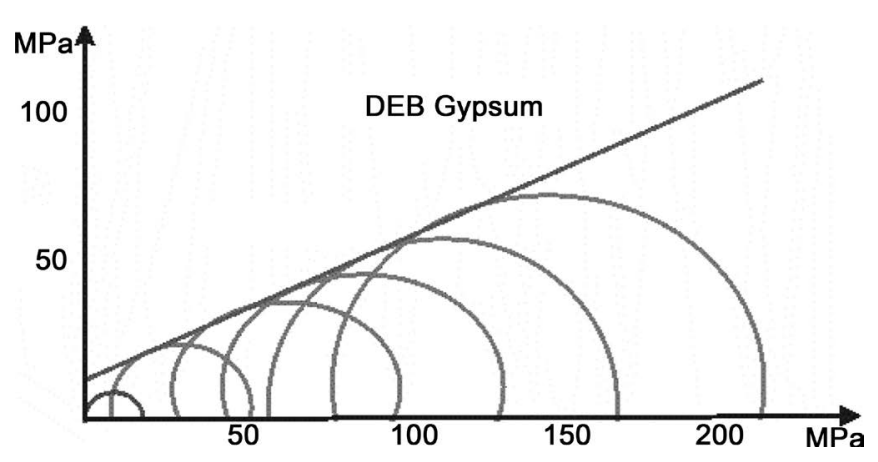

Figure 8. Mohr circles for gypsum from the Mellegue area. 


\section{Industrial Application of Debadib Gypsum}

The natural gypsum deposit of Debadib region (North-West of Tunisia) showed favorable physicochemical properties related to its industrial application. Among the practical applications, we can think the industrial plastering today reached a Tunisian threshold of 320,000 tonnes per year. Other applications may include glue and mortar, decorations, building products. Comparing the product from Debadib deposit with Tunisian products marketed (Mestaoua and Meknassy) and other product (Lafarge) we can deduce certain customary items related to the parameters analyzed. Based on their chemistry and mineralogy (Figure 9 and Figure 10), plaster of Debadib region showed a promising chemistry with $\mathrm{SiO}_{2}$ and $\mathrm{MgO}$ rates are significantly lower than Meknassy (Tunisia) and Lafarge (France), $\mathrm{Al}_{2} \mathrm{O}_{3}$ and $\mathrm{Fe}_{2} \mathrm{O}_{3}$ rates are significantly higher compared to other samples and does not exceed $0.2 \%$. Gypsum derived from gypsum Debadib appears similar to that of Meknassy in having an average percentage of $32 \% \mathrm{CaO}$ and an average percentage of $42 \% \mathrm{SO}_{3}$ against slightly higher percentages for plaster Mestaoua

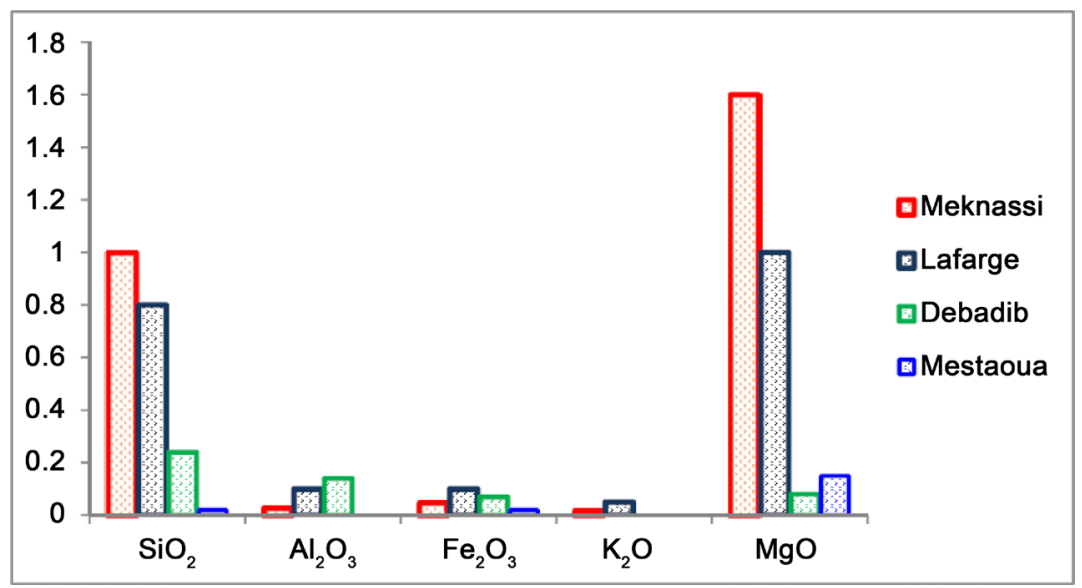

Figure 9. Comparison of chemical elements (trace elements) between the gypsum deposit of jbel Debadib, and Mestaoua, Meknassy and Lafarge deposits.

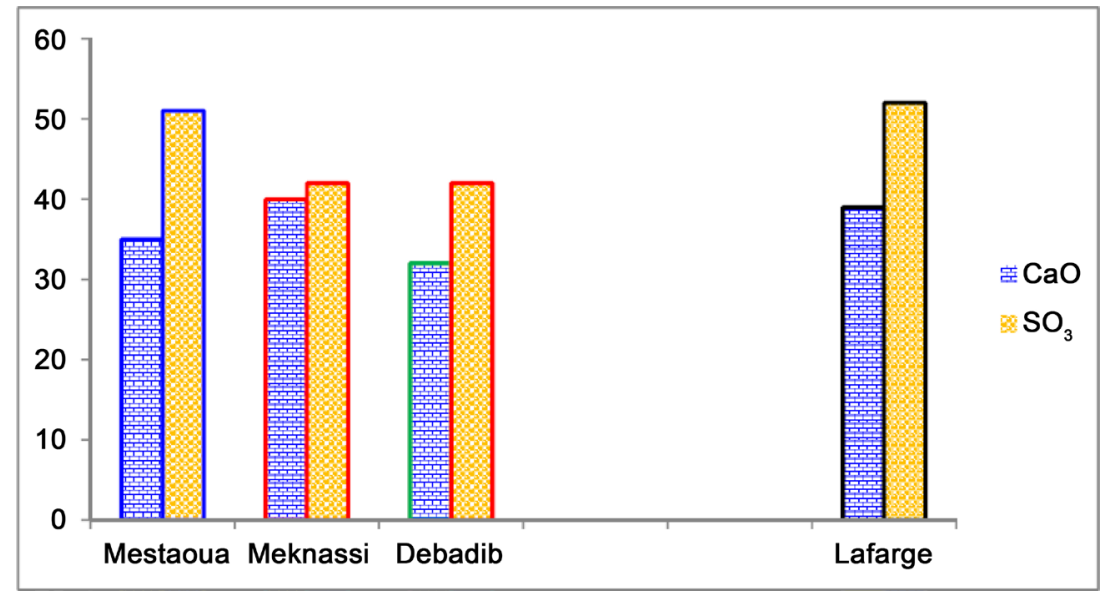

Figure 10. Comparison of chemical elements (major elements) between the gypsum deposit of jbel Debadib, and Mestaoua, Meknassy and Lafarge deposits. 
and Lafarge (France). For further characterization of plaster Debadib, it was essential to check certain requirements plastering materials as suggested by the "National Union of gypsum industries" [8]. These specifications include various physical properties such as mechanical strength, porosity and water absorption. The mechanical behavior of plaster is regarded as an important parameter for the selection of raw foods for the manufacture of gypsum. Badens et al. [39] investigated the relationship between the mechanical properties (Young's modulus) and a set of plaster samples. They concluded that the Young's modulus is strongly influenced by moisture. Gypsum Debadib showed slight variations in module and mechanical resistance values favorable (Table 3). The Debadib gypsum deposit was also compared to adhesives (bonding plaster) made from gypsum Meknassy (Central Tunisia). He presented similarity to that of Meknassy (glue Meknassy) including a high adhesive capacity, a fineness of grains and a usage flexibility ranging from one to two hours. Also these data indicate that the gypsum Debadib demonstrated the adequacy of its intrinsic characteristics with all industrial application requirements. Thereby, the gypsum of Debadib area may be considered an excellent candidate for the production of several gypsum products.

\section{Conclusion}

Gypsum is an evaporitic rock which is widely distributed throughout the Triassic deposit in the North West of Tunisia. The mineralogical analysis indicated high purity gypsum (95\% gypsum) with traces of clay minerals and calcite. The specific gravity values of the gypsum studied were close to the published value for the pure substance. All the samples had low density and exhibited a moderate porosity, whether effective or absolute. The gypsum proved to be moderately strong when tested in unconfined compression and tensile strength. Triaxial testing values indicated favorable values of apparent cohesion and angle of friction compared with those quoted in the literature. The whiteness index proved a high degree. The setting time can be considered short and medium. Therefore, we can conclude that the gypsum of the Debadib area can be considered as a potential source for industry. According to the Tunisian standard NT 47.66-1 [40], the Debadib gypsum can be used to produce respectively plaster type B (plasters for construction) or to produce plaster type C (staff Plasters, acoustic Gypsum Plaster insulation, plaster for protection against fire) [41]. In addition to that, gypsum can be used for chemistry, agriculture and cement manufacture and has similarity with the Jurassic southern gypsum deposit.

\section{Acknowledgements}

We acknowledge contributions from the engineers of Tunisian Technical center of construction materials, ceramics and glass laboratory (CTMCCV) and all technical laboratory team of Tajerouine Cement manufacturing (CIOK).

\section{References}

[1] Burollet, P.F. (1973) Importance of Saliferous Factors in Tunisian Tectonics. Annales Mines 
and Geology, No. 26, 110-120.

[2] Busson, G. (1974) The Evaporite Trias of North Africa and Western Europe: Data on Paleogeography and Deposition Conditions. French Society of Geology, No. 6, 653-665. https://doi.org/10.2113/gssgfbull.S7-XVI.6.653

[3] Jouirou, M. (1981) Geological and Geotechnical Study of the Sediments of the Kef Region North West of Tunisia. Thesis 3rd Cycle, Univ Bordeaux I, 146.

[4] Ghanmi, M. (1980) Geological Survey of Djebel Kabbouch (Tunisia Spetentrionale). Thesis 3rd Cycle, Univ. Paul Sabatier, Toulouse, 119.

[5] Adil, S. (1993) Dynamics of the Triassic in the North of Tunisia: Basin in Multiple Relay of Decay, Magmatism and Mining Implications. Thesis 3rd Cycle, Univ. Tunis II, 217.

[6] Biely, A. and Rakus, M. (1972) Critical Analysis of Data on the Age of the Spring in Northern Tunisia. Geology of Tunisia, No. 38, 35-48.

[7] Chikhaoui, M. (2002) The Diapir Zone in Tunisia: Structural Framework and Geodynamic Evolution of Meso-Cenosoic Sedimentation and Geometry of Triassic Bodies. Thesis, Univ. Tunis II, 323.

[8] Daligand, F., et al. (1982) Plaster: Physico-Chemistry, Manufacturing and Jobs. Boulvard Saint-Germain, Paris.

[9] Garrido, F., Illera, V. and Garcia-Gonzalez, M.T. (2005) Effect of the Addition of Gypsumand Lime-Rich Industrial by Products on $\mathrm{Cd}, \mathrm{Cu}$ and $\mathrm{Pb}$ Availability and Leachability in Metal-Spiked Acid Soils. Applied Geochemistry, 20, 397-408.

[10] Han-Cheol, C., Hori, M., Yoshida, T., Yamada, N., Komada, Y., Tamaki, Y., et al. (2014) Tri-Calcium Phosphate ( $\mathcal{B}$-TCP) Can Be Artificially Synthesized by Recycling Dihydrate Gypsum Hardened. Dental Materials Journal, 33, 845-851. https://doi.org/10.4012/dmj.2014-040

[11] Kojima, Y. and Yasue, T. (2006) Synthesis of Large Plate-Like Gypsum Dihydrate from Waste Gypsum Board. Journal of the European Ceramic Society, 26, 777-783. https://doi.org/10.1016/j.jeurceramsoc.2005.06.018

[12] Mansour, M.B., Soukaina, C.A., Benhamou, B. and Jabrallah, S.B. (2013) Thermal Characterization of a Tunisian Gypsum Plaster as Construction Material. Energy Procedia, 42, 680 688. https://doi.org/10.1016/j.egypro.2013.11.070

[13] San-Antonio-González, A., Del Río Merino, M., Arrebola, C.V. and Villoria-Sáez, P. (2015) Lightweight Material Made with Gypsum and Extruded Polystyrene Waste with Enhanced Thermal Behaviour. Construction and Building Materials, 93, 57-63. https://doi.org/10.1016/j.conbuildmat.2015.05.040

[14] Singh, N.B. and Middendorf, B. (2007) Calcium Sulfate Hemihydrate Hydration Leading to Gypsum Crystallization. Progress in Crystal Growth and Characterization of Materials, 53, 57-77. https://doi.org/10.1016/j.pcrysgrow.2007.01.002

[15] Zhang, D., Yuan, Z., Wang, S., Jia, Y. and Demopoulos, G.P. (2015) Incorporation of Arsenic into Gypsum: Relevant to Arsenic Removal and Immobilization Process in Hydrometallurgical Industry. Journal of Hazardous Materials, 300, 272-280. https://doi.org/10.1016/j.jhazmat.2015.07.015

[16] Zhou, J., Liu, C., Shu, Z., Yu, D., Zhang, Q., Li, T. and Xue, Q. (2015) Preparation of Specific Gypsum with Advanced Hardness and Bending Strength by a Novel In-Situ Loading-Hydration Process. Cement and Concrete Research, 67, 179-183. https://doi.org/10.1016/j.cemconres.2014.09.004

[17] Bouaziz, S., Barrier, E., Soussi, M., Turki, M.M. and Zouari, H. (2002) Tectonic Evolution of the Northern African Margin in Tunisia from Paleostress Data and Sedimentary Record. 
Tectonophysics, 357, 227-253. https://doi.org/10.1016/S0040-1951(02)00370-0

[18] Ali, F.B., Iucolano, F., Liguori, B., Piscopo, D., Marino, O. and Caputo, D. (2016) Physical and Mechanical Characterization of Sun-Dried Bricks. A Case History: The Galeb of Kebili. Materials and Structures, 49, 159-165.

[19] Sdiri, A., Higashi, T., Bouaziz, S. and Benzina, M. (2014) Synthesis and Characterization of Silica Gel from Siliceous Sands of Southern Tunisia. Arabian Journal of Chemistry, 7, 486493. https://doi.org/10.1016/j.arabjc.2010.11.007

[20] Jauzein (1967) Contribution to the Geological Study of the Confines of the Tunisian Ridge (Northern Tunisia). Annales Mines Geology, (Tunis) 22/4.

[21] Villa, J.M. (1994) Discovery in Tunisia at the SW of the Kef of Triassic Material Interstratified in the Albian: Extension of the Domain "Salt Glacier" under the Algerian-Tunisian Confines. Report of the Paris Academy of Sciences, 318, 109-116.

[22] Villa, J.M., et al. (1995) Halocinesis Distensive Albien with Submarine "Salt Glaciers" and Tertiary Folding of the Sector Ouenza-Ladjebel-Meridef: Details following the Article of A. Bouzenoune, H. Rouvier and J. Thibiéroz, “Trias de l'Ouenza: Diapiric context, mineralogical zonation and metallogenic consequences". Geological Service Bulletin (Algéria), 2, 135.

[23] Bolze, J. (1954) Ascension and Breakthrough of the Middle Cretaceous Diapirs in the Mounts of Téboursouk. Cr. Somm. French Society of Geology, 139-141.

[24] Bolze, J. (1955) Presence of the Wealdian in the Diapir Zone Saliferous Series (Northern Tunisia). Geological Service Bulletin, t. 240, No. 11, 2103-2105.

[25] Bolze, J. (1957) Attribution to the Jurassic of Part of the North Tunisian Saline Series. Cr. Somm. French Society of Geology, 4, 74-75.

[26] Gottis, S. (1954) General Observations on the Tunisian Triassic. French Society of Geology, $12,262-266$.

[27] Murat, M. and Foucault, M. (1977) Calcium Sulphates and Derived Materials. International Colloquies of RILEM, Saint Remy les chevreuses, France.

[28] Karmazsin, E. (1978) Kinetics and Mechanism of Hydration of Calcium Sulphates. Study by Calorimetry in Isothermal Regime. PhD Thesis of INSA Lyon, 150.

[29] Triollier, M. (1979) Hydration of Calcium Sulphate Hemihydrate. Doctoral Thesis of the University of Grenoble, France.

[30] Standard NF EN 13279-2 (2005) Plaster and Plaster Based Plaster for Building-Part.

[31] Coquard, P. (1992) Mechanical Strength of Dry and Wet Plasters. PhD Thesis of the University of Aix-Marseille III, France, 93.

[32] Standard X08-011 (2012) French Experimental Standard for Determining the Whiteness Index.

[33] Barriac, P. (1986) Swelling of the Plaster. Lafarge Internal Report.

[34] Standard EN 196-3 (2005) Method for Determining the Consistency of Gypsum.

[35] Standard NF P 94-074 (1994) Triaxial Revolution Test-Apparatus.

[36] Hoek, E. (1983) The Strength of Jointed Rock Masses. Géotechnique, 33, 187-223. https://doi.org/10.1680/geot.1983.33.3.187

[37] IAEG (1979) Classification of Rocks and Soils for Engineering Geological Mapping Part 1: Rock and Soil Materials. Bulletin of the International Association of Engineering Geology, 19, 355-371.

[38] Deer, W.A., Howie, R.A. and Zussman, J. (1962) An Introduction to the Rock Forming 
MINERALS. Longmans, London, 528 p.

[39] Badens, E., Veesler, S., Boistelle, R. and Chatain, D. (1999) Relation between Young's Modulus of Set Plaster and Complete Wetting of Grain Boundaries by Water. Colloids and Surfaces A: Physicochemical and Engineering Aspects, 156, 373-379.

https://doi.org/10.1016/S0927-7757(99)00097-7

[40] PNT 47.66-1 (2007) Plasters and Plaster Based Plaster for Building. Part 1: Definition and Specifications.

[41] PNT 47.66-2 (2007) Plasters and Plaster Based Plaster for Building. Part 2: Test Methods.

Submit or recommend next manuscript to SCIRP and we will provide best service for you:

Accepting pre-submission inquiries through Email, Facebook, LinkedIn, Twitter, etc.

A wide selection of journals (inclusive of 9 subjects, more than 200 journals)

Providing 24-hour high-quality service

User-friendly online submission system

Fair and swift peer-review system

Efficient typesetting and proofreading procedure

Display of the result of downloads and visits, as well as the number of cited articles

Maximum dissemination of your research work

Submit your manuscript at: http://papersubmission.scirp.org/

Or contact ojg@scirp.org 